\title{
Kulturel kapital og social differentiering
}

\author{
Hvad Bourdieus begreb kulturel kapital kan bidrage med i en diskussion af effekter \\ af en ulige fordeling af goder
}

\section{Staf Callewaert}

Professor emeritus, Københavns universitet

\begin{abstract}
Artiklen udgør optegnelserne til en forelæsning på Socialforskningsinstituttets konference 6.-7. oktober 1994.

Indledningsvis kommenteres selve konferencens problemstilling: Hvad den samfundsvidenskabelige forskning kan tilbyde når det gælder at begrebsliggøre systematiske sociale, kulturelle og økonomiske forskelle i befolkningens livsvilkår. Mere konkret: Hvad Bourdieus begreb kulturel kapital kan bidrage med i en diskussion af effekter af en ulige fordeling af goder. Begrebet "forskelle" fremhæves indledningsvis som problematisk fordi man udsætter sig for en indbygget orientering mod tanken om at man i det mindste kan tænke sig en befolkning uden systematiske forskelle i livsvilkår mellem grupperne.

Begrebet "kulturel kapital" resumeres og diskuteres, og der relateres til en skriftløs etnisk gruppering i Vestafrika (Ballanta i Guinea-Bissau) uden en central politisk overhøjhed som holdes sammen af en magt som i sidste instans er forlagt til den usynlige del af den samlede gruppe af deltagere, en forfaderskult. Vores politiske tænkning har siden den engelske, den amerikanske og den franske revolution opereret med modeller hvor bæreren af et politisk herred $\varnothing \mathrm{mme}$ i sidste instans er de sig imellem ligestillede medborgere i forening. En sådan forestilling udgør en ideologisk konstruktion på lige fod med forfaderstroen.

Bourdieus forståelse af begrebet "kultur" indebærer ikke kultur stillet mod natur, men kultur som den side af den menneskelige virksomhed som er symbolsk. Der perspektiveres til andre forståelser
\end{abstract}

\footnotetext{
Denne artikel udgør optegnelserne til en forelæsning på en konference om levevilkår på Socialforskningsinstituttet i København 6.-7. oktober 1994. Det som dengang betegnedes Socialforskningsinstituttet, i artiklen forkortet SFI, hedder nu Det Nationale Forsknings- og Analysecenter for Velfærd, forkortet VIVE. I artikeln benyttes den gamle betegnelse og forkortelse. Artiklen er i en anden udgave publiceret som Callewaert (2003).
}

Publisert: 28.05.2021

Praxeologi - Et kritisk refleksivt blikk på sosiale praktikker (C2021 Staf Callewaert

DOI: http://dx.doi.org/10.15845/praxeologi.v3i0.3296 
af især "kapital" og "økonomi", og det konstateres at den økonomiske økonomi i moderne samfund har sine egne forfaderskulter, det vil sige sine egne symbolske strukturer som på en særegen måde organiserer miskendelsen af udenom- økonomiske interesser, på samme måde som primitive symbolske strukturer organiserer miskendelsen af $\varnothing$ konomiske interesser.

I skolen antages det at præstationerne afhænger af arbejdsomhed og evner, men de afhænger snarere af dispositioner hvis erhvervelse er stærkt forbundet med den enkeltes biologiske egenskaber og første opvækstvilkår, og forudsætter ikke nødvendigvis en bevidst indprentning. Det gør at sammenblandingen af arv og præstation okkulteres. Erhvervelsens distinktive kendetegn tenderer mod at være vældigt upåfaldende og tilsyneladende uvæsentlige karakteristika, som for eksempel en accent i sproget eller en måde at gå på; karakteristika omfattet af begrebet "kulturel kapital".

Nøgleord: kulturel kapital, kapital, økonomi, økonomisk økonomi, Bourdieu, praxeologi 


\section{Nogle kommentarer til selve problemstillingen som den er formuleret af konferencen}

Om nødvendigheden af at se ikke kun på effekter af en ulige fordeling af goder, men snarere på opkomsten og funktionen (genesen og strukturen) af en måde at producere og håndtere sociale relationer på, som resulterer i en ulige fordeling og anvendelse af goder.

Spørgsmålet er om man skal følge indbydelsen, hvad den samfundsvidenskabelige forskning har at tilbyde når det gælder at begrebsliggøre systematiske sociale, kulturelle og økonomiske forskelle i befolkningens livsvilkår, det vil sige om den sociale differentiering og dens nuværende udvikling. I denne sammenhæng er det mere specifikke spørgsmål hvilket bidrag Bourdieu tilbyder, med bl.a. begrebet "kulturel kapital". Jeg vil bare indledningsvis kommentere visse af disse formuleringer.

Vi ved alle hvor problematisk det kan være at benytte sig af begrebet "forskelle". Ved at benytte dette begreb udsætter man sig for den pr. kontrast indbyggede orientering mod tanken om at man i det mindste kan tænke sig en befolkning uden systematiske forskelle i livsvilkår mellem grupperne.

Dette er i og for sig ikke så underligt. Jeg har i mange år studeret et såkaldt primitivt samfund i Vestafrika (Ballanta i Guinea-Bissau), eller rettere sagt en skriftløs etnisk gruppering, udformet gennem en kombination af slægtsforhold og territoriale enheder, som savner en central politisk overhøjhed. Om den plejer jeg at sige, hvis jeg meget forenklet og hurtigt skal give en karakteristik, at i dette samfund er alle bosættelser og alle de ældste mænd som er bosættelsernes overhoveder, lige med hinanden når det gælder systematiske livsvilkår. Det er desuden utroligt fascinerende at opdage hvordan alt i dette samfund medvirker til, og altså må tænkes at være i det mindste før-bevidst anlagt for at opretholde denne lighed over tid, det vil sige over de påfølgende reproduktionscykler som udgøres af generationerne. Differentieringen findes inden for bosættelsen.

Den erfaring er ganske vigtigt fordi den forlægger kontrasten fra tankekonstruktioner til den virkelighed man har erfaring med.

Men naturligvis halter sammenligningen fordi det vi i vore samfund betegner klasser eller fraktioner eller grupper, slår en række enkeltindivider sammen på en måde som ikke har sit modstykke i det ballante samfund. Dér er den mindste enhed bosættelsen, og derfor spiller dens interne differentiering på sin vis ingen afgørende rolle. Det samme kan man ikke sige om vores samfund hvor den mindste enhed trods alt er den enkelte.

Men i det mindste i én henseende opdager man efterhånden et hierarki selv blandt de ældste mænd som forkropsligg ør deres bosættelser: det er i det vi ville kalde det politiske, og som fremtræder som det religiøse for vores blik som altid allerede har indført en uddifferentiering mellem for eksempel det religiøse og det politiske. I virkeligheden handler det om en forening af begge dimensioner som ligger før en sådan uddifferentiering. Den enkelte bosættelse, den territoriale sammenslutning og det bredere slægtsskabsbånd indgår i hierarkiserede relationer mellem de ældste med den ældste af de ældre i toppen i den synlige verden. Og dette hierarki har sin forlængelse i den anden halvdel af deltagerne i grupperingen som lever på den anden side af grænsen for den verden som er synlig for hverdagens øjne, forfædrenes verden. Det er også på denne måde der opstår ikke en separeret, men en integreret centraliseret politisk magtud $\varnothing v e l s e$. Man har udtrykt dette sådan at akefale samfund holdes sammen af en magt som i sidste instans er forlagt til den usynlige del af den samlede gruppe af deltagere.

Jeg bringer dette på tale fordi det forekommer mig at man måske burde tilføje de politiske livsvilkår, i første omgang til opregningen af de sociale, kulturelle og økonomiske. For det er meget muligt at des Pudels Kern er netop dér. Så vidt jeg ved, er der intet samfund uden politisk herredømme, og det tvinger os måske til at forlade dikotomien ligheder/forskelle i systematiske livsvilkår som i sidste instans ufrugtbar, selv som tankevækker. Både i grupperingen som helhed og 
inden for gruppen udøves herredømme, i dette tilfælde bl.a. i forening med en kønsmæssig og aldersmæssig fordeling af det sociale arbejde: Det er mænd der hersker over kvinder og yngre, inklusive når de i en vis udstrækning deler det med kvinderne i de matrilineære samfund. Skønt det er ikke særligt dækvat at pludselig aggregere kvinder og yngre på denne abstrakte måde. I virkeligheden er hvert enkelt konkrete individ altid allerede indehaver af en strukturel position som slægtning af et vist køn og en vis alder i en kompleks kvalitativ struktur som ikke fanges af en sådan abstrakt aggregering. For at feminismen skal have en mening, må det først handle om det frisatte enkelte individ.

Nu ved jeg meget vel at vores politiske tænkning lige siden den engelske, den amerikanske og den franske revolution har opereret med modeller hvor selv bæreren af det politiske herred ømme i sidste instans er de sig imellem ligestillede medborgere i forening. Men dette er en ideologisk konstruktion på lige fod med forfaderstroen. Den dækker over fundamentale forskelle mellem herredømme og underkastelse. Disse forskelle udtømmes overhovedet ikke af beskrivelser af fordelingen af resurser mellem individer og grupper for at, som det hedder, deltage i det politiske liv. Det handler præcis om at deltage i en funktion som er skel-sættende.

Det har altid slået mig at når man læser prominente historikere, så er deres urokkelige forantagelse dette $n \varnothing d v e n d i g e$ herred $\emptyset \mathrm{mme}$ i politisk henseende, som på sin vis ligger f $\varnothing \mathrm{r}$ alle overvejelser over hvordan fordelingen af resurser er beskaffet.

Og dermed kommer vi måske til en anden for-bemærkning om vores præliminære begrebsapparat. Selv begrebet livsvilkår er måske problematisk fordi det situerer sig så at sige på konsumtionsniveau: Hvilke midler har den enkelte eller grupper til deres rådighed? - underforstået for at deltage i forskellige aktiviteter som i princippet er tilrettelagt så alle kan deltage på lige fod, bare de har de tilsvarende resurser. Det som dermed ikke kommer i fokus, er dels selve gennemførslen af forelingen (og ikke bare de fordelte resurser til forbrug), men også opkomsten af disse resurser, opkomsten af fordelingen, opretholdelsen af både det ene og det andet og beskaffenheden af de aktiviteter man skal deltage i med disse resurser.

Dette er i og for sig et gammelt stridsspørgsmål omkring hele komplekset af klasseanalysen, men det er ikke mindre relevant for det. En klassisk kritik af næsten alle analyser af sociale strukturer er at de går ind på konsumtionsniveauet og miskender at produktion og distribution sætter rammerne for konsumtionen. Dette gælder ikke bare varer og tjenesteydelser, men sociale forhold det hele taget.

Sagt på en anden måde: Man lærer sig formodentlig ikke særligt meget om et samfund ved at man giver en beskrivelse af forskelle i tilgang til allerede producerede og fordelte goder og tjenester og tilsvarende måder at anvende dem, med mindre man siger noget om hvordan denne sammenhæng skabes og opretholdes.

Måske betyder det kun at man skal være bevidst om de begrænsninger som ligger i vore nu mere traditionelle levevilkårsunders $\varnothing$ gelser.

Bourdieus begreb "kulturel kapital" kan man naturligvis opfatte som en særlig måde at beskrive uddannelsesvariablens betydning som uafhængig variabel med en selvstændig gennemslagskraft ved siden af andre såsom $k \varnothing n$, social herkomst eller tilhør, indkomst, formue osv.. Hvorefter man kan benytte dem som forklarende faktorer for et observeret adfærdsmønster i forskellige sammenhænge, betragtet som afhængige variabler. Bourdieu er meget skeptisk mod hele proceduren, men ikke helt fremmed for noget i den stil.

Man kommer allerede et skridt længere hvis man desuden spørger hvordan fordelingen af denne kulturelle kapital på grupper og individer kommer i stand. Men det mest afgørende spørgsmål gælder hvilken rell kulturel kapital (banalt udtrykt formel uddannelse med hele vedhænget, i det mindste i vores samfund) og det relativt selvstændige felt af kapitaldannelse og fordeling spiller i den samfundsmæssige helhed, helt uanset hvordan det er fordelt, og hvordan denne fordeling påvirker anvendelsen. Det er et af grundproblemerne med variabel-sociologi, at den kan sige noget om 
variationer, men ikke siger noget om hvad det er der varierer, eller hvordan variationen opstår og opretholdes. Sagt på en banal måde: det afgørende for en sociologisk beskrivelse og forklaring af et samfund er ikke at kortlægge uligheder i den faktiske fordeling af tilgang til bl.a. en kulturel kapital. Det afgørende er end ikke hvordan disse uligheder opstår og opretholdes. Det afgørende er hvilken rolle den faktor spiller: Hvordan kan det være at undertrykkelse og udbytning opretholdes på en legitim måde? Med andre ord og i Bourdieus termer: hvordan kan kulturel kapital også være symbolsk kapital?

[...] symbolic capital, which is the form that one or another of these species [økonomisk, kulturel respektive social kapital, SC] takes when it is grasped through categories of perception that recognize its specific logic or, if you prefer, misrecognize the arbitrariness of its possession and accumulation (Bourdieu \& Wacquant, 1992, p. 119).

Mange, blandt dem Donald Broady, har haft vanskeligt ved præcis at skelne mellem symbolsk kapital og kulturel kapital. Det er heller ikke så enkelt hvis man forfølger Bourdieus forskellige formuleringer gennem forfatterskabet. Men både i teksten "Forms of capital" (Bourdieu, 1983/1986) og i ovenstående tekst som er blandt de seneste, suggereres i alle tilfælde følgende mulige fortolkning: Vi taler om symbolsk kapital når en af de ovennævnte kapitalformer fungerer pr. erkendelsen af dens gyldighed og altså pr. miskendelsen af dens virkelige grundlag, på en måde som har selvstændiggjort sig. Lidt banalt udtrykt: Når en uddannelsestitel har sin gennemslagskraft primært fra den tiltro og værdsættelse den nyder inden for et felt eller på et marked som en selvstændig størrelse. At kunne tale Oxbridge-engelsk i stedet for engelsk fra forstæderne i London eller Chicago kan fungere som en kapital med enorm gennemslagskraft, fuldkommen uafhængig af enhver funktionel sammenhæng hvor forstadssproget kunne være det mest adækvate instrument. Det virker af sig selv, gennem sin rene symbolværdi, som signalement, i den udstrækning det bliver anvendt og modtaget med denne tiltro. I grænsetilfælde kan faktisk alt hvad dette signalement står for, gå tabt. Den rene symbolværdi er en resurse for sig.

Eller med andre ord: Vi leder efter et svar på det evige spørgsmål "hvordan er samfundet muligt?" for at kunne situere observerbare forskelle i tilgang til resurser af forskellig slags. Og da kan man ikke klare sig uden herred $ø$ mme-dimensionen i bredeste mening. En grundantagelse om socialt liv er at det har at gøre med at lede og fordele socialt arbejde.

Det vil sige: for at forstå hvad der menes med kulturel kapital, må man se begrebet inden for rammen af et fors $\varnothing \mathrm{g}$ på at formulere en overgribende sociologisk teori (ikke en social teori) som vil være en økonomi af de på hinanden artikulerede, relativt selvstændige sociale praktikker, hvor den praktiske sans, begrebsliggjort som habitus, udgør artikulationen mellem de forskellige felter af praktikker.

Som Broady har vist det i sin afhandling (Broady, 1991), må man tage begreberne kapital, felt og habitus under ét for at forstå deres indhold og betydning.

\section{Hvad menes med "økonomi", "kapital", "felt", "habitus" og "strategi"?}

\section{1. Praktikkernes $\varnothing$ konomi og kapital}

Dermed kommer vi også til et meget følsomt punkt, nemlig anvendelsen af begreberne "praktikkernes økonomi" og "kapital". Det kan virke som om disse begreber dannes i analogi med begreber som vi kender både fra hverdagssproget og fra den akademiske disciplin "økonomi", men som bliver omdefineret, hvilket betyder at de både bevarer en del og mister en del af deres indhold og betydning i deres oprindelige kontekst. 
Bourdieu mener desuden at dette er en overfladisk måde at se på sagen. Han mener at det egentlig er omvendt: Den moderne økonomiske videnskab har taget monopol på begrebsapparatet, efter at have reduceret begrebernes indhold og betydning til et yderst smalt felt; et begrebsapparat som egentlig fra begyndelsen har en meget bredere reference, nemlig husholdningen med alle sociale praktikker.

Jeg synes godt om Broadys formulering i denne sammenhæng når han skriver at Bourdieu fornægter at den akademiske disciplin "økonomi" har forrang i fortolkningen i spørgsmålet selv om den kapitalistiske $\varnothing$ konomi, for slet ikke at tale om førkapitalistiske $\varnothing$ konomier eller samfundsteorier i det hele taget (jf. Broady 1991, s. 202).

Det er endnu mere fantastisk at se, ikke alene i vore dage, men stort set lige siden konstituteringen af videnskabelige diskurser om det sociale, hvordan den reducerede indsnævrede $\varnothing$ konomiske $\varnothing$ konomis logik efter den operation gør krav på at tilbyde en universel logik for alle sociale praktikker.

Hos Bourdieu anvendes begrebet kapital ikke i sin hverdagsbetydning, men heller ikke hverken i den tekniske betydning begrebet har i den marxistiske kritik af den politiske økonomi, eller i den neoklassiske økonomiske videnskab. Det samme gælder for begrebet "praktikkernes økonomi".

Der er ingen tvivl om at Bourdieus ambition er at vriste disse begreber ud af hænderne på $\emptyset$ konomerne og deres analyse af det som opfattes som et selvstændigt felt i et typisk moderne

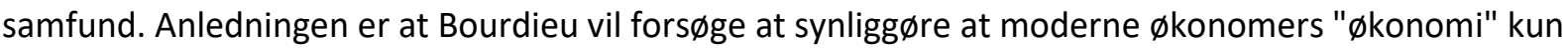
er en underafdeling af en økonomi som kan benyttes som betegnelse på den samfundsmæssige helhed, opfattet som en $\varnothing$ konomi af praktikker. Med det forsøger han at slippe for opfattelsen af at kun den $\varnothing$ konomiske $\varnothing$ konomi er en $\varnothing$ konomi, det vil sige organiseret på grundlag af (legitime) interesser. Det han vil have frem, er to ting:

- Dels at alle felter, inklusive for eksempel videnskabens - for nu at sætte tingene på spidsen - i deres egen logik alligevel er styret af en interesselogik og ikke af logik kort og godt. De kan med rette opfattes som en $\varnothing$ konomi på lige fod med den økonomiske $\varnothing$ konomi, dog med et differentieret indhold og betydning

- Dels at den samfundsmæssige helhed består af særskilte artikulationer af alle disse "økonomier", hvilket giver os en økonomi af praktikker, en specifik type af husholdning med alle relativt selvstændige praktikker.

Det er derfor Bourdieu efterhånden definerer den videnskabelige virksomhed ikke som en virksomhed som maksimalt holder sig fri af interesser, bortset fra efters $\emptyset$ gningen af sandheden, men som en virksomhed som maksimalt tilrettelægges sådan at den interne og de eksterne interesser befordrer eftersøgningen efter sandheden.

Det betyder omvendt også at Bourdieu ikke vil acceptere at man udtømmende kan beskrive den $\varnothing$ konomiske $\varnothing$ konomi, selv under den etablerede kapitalisme, som styret af ren $\emptyset$ konomisk logik sådan som den økonomiske teori forudsætter. Det overtydelige fravær af en økonomisk økonomi, både i gerninger og i tanker, i et før-moderne samfund er bare et særtilfælde af en praktikkernes $\varnothing$ konomi. Den $\varnothing$ konomiske $\varnothing$ konomi i et moderne samfund har sine egne forfaderskulter, det vil sige sine egne symbolske strukturer som på en særegen måde organsierer miskendelsen af udenom$\emptyset$ konomiske interesser, på samme måde som den primitive symbolske struktur organiserer miskendelsen af økonomiske interesser. Derfor taler Bourdieu også konsekvent om kapital inden for alle felter.

Dette betyder naturligvis ikke at sociologien reduceres til den økonomiske økonomi, eller at den bagvedliggende filosofi er utilitarismen, eller at den af Weber/Habermas så brilliant illustrerede proces af uddifferentiering af relativt selvstændige felter som kendetegn på det moderne, igen bliver reduceret. Det betyder heller ikke at man hopper over det vi lærte os af Marx, at man ikke kan 
begrebsligg øre før-kapitalistiske samfund med et begrebsapparat som er hentet fra begrebsliggørelsen af kapitalismen. Disse begreber anvendes ikke univokt, men analogt, og de får i hvert tilfælde deres bestemmelse af en begrebslig afklaring af den samfundsformation og det felt som er på tale.

Man kan have forskellige meninger om hvor vellykket dette program gennemføres, men man skulle gerne undgå at allerede fra begyndelsen tolke det helt forkert, trods alle Bourdieus advarsler, og på trods af at man kan se redskabet i værk i en mængde undersøgelser.

Bourdieu fastholder at han ikke overfører en tankemåde som har sit udspring i den økonomiske praktik og videnskaben til andre domæner, men at han genfortolker denne økonomiske tankemåde (og dens aflæggere inden for sociologien i form af den rationelle handlingsteori) på baggrund af en mere grundlæggende generel opfattelse som så at sige kommer først.

Naturligvis ville det være interessant at sammenligne denne måde at tænke på med for eksempel Habermas' Teorien om den kommunikative handlen (Habermas, 1981/1996) eller med human capitalteorien, men det kan vi ikke gøre her. Jeg kan kun signalere at Bourdieu i særlige artikler udførligt har problematiseret for eksempel anvendelsen af interesse-begrebet.

Som en illustration kan man henvise til det Bourdieu siger om et andet, beslægtet begreb, "investering", eller snarere: tilbøjeligheden til investering. Jeg oplever at han tolker dette begreb lidt i samme mening som i psykoanalysens driftsøkonomi:

By investment I mean the propensity that is born of the relation between a field and a system of dispositions adjusted to the game it proposes [...] that implies at once an inclination and an ability to play the game [...]. (Bourdieu \& Wacquant, 1992, s. 118)

Med andre ord tilbøjligheden til at satse som drivkraft og en kompetence som opstår når ens dispositioner og omgivelserne passer til hinanden, det vil sige når omgivelserne lader sig besætte med min besathed. Entreprenørens kvasi-automatiske investeringsadfærd i en veletableret kapitalistisk $\varnothing$ konomi er bare en variant af en generel analog struktur.

\section{2. Habitus}

Om begrebet habitus har jeg selv skrevet en bog (1992). Her vil jeg nøjes med at pege på nogle aspekter: Man kan sige at Bourdieu med habitus (som er et teoretisk, ikke et empirisk-deskriptivt begreb, som i så fald skulle være den praktiske sans) mener en for en social gruppe (eller et enkeltindivid) samlende princip for en gruppe af homologe dispositioner. Det han vil opnå med begrebet, er:

1. At forankre sociale praktikker på det forkropsliggjorte, før-bevidste niveau hvor de i sidste instans har deres kognitive og motivationelle udspring stik imod det forskellige rationalistiske handlingsteorier antager (hvilket ikke skal tolkes som at disse praktikker er irrationelle, eller at bevidst overlagt regelstyrede handlinger ikke forekommer).

2. At byde på en forklaring af den tilsyneladende, i forvejen etablerede harmoni mellem objektive strukturer som betinger handlingerne, og de internaliserede handlingsdispositioner.

3. At forklare sammenhængen mellem forskellige felter, eller praktikker inden for forskellige felter (fx spørgsmålet om forholdet mellem basis og overbygning i vulgær-marxismen) gennem at udpege et samlet førbevidst orienteringsprincip som i forskellige transformeringer ytrer sig inden for de forskellige felter. Dette giver en forklaring på homologien mellem forskellige felter og dermed på den samfundsmæssige enhed. 


\section{3. Strategi}

Mod tendensen til alene at forlægge interessestyrede handlinger til økonomien og til at lade andre felter være styret alene af andre logikker, udvikler Bourdieu sit begreb "praktikkernes $\emptyset$ konomi". Her kommer en fundamental forskel til Habermas til syne, sådan som Bourdieu selv har påpeget det (i Bourdieu \& Wacquant, 1992). Ifølge Bourdieu kan man i en videnskabelig analyse ikke tage den moderne selvforståelse på ordet når den forstår den moderne uddifferentiering mellem målrationel teknisk eller strategisk målrationel, moralsk-praktisk værdirationel handling og autentisk ekspressiv handling med tilsvarende kognitive diskurser som gennemført eller gennemførlig. På en analog måde er al handlen strategisk, ikke bare på grund af en utilbørlig kolonisering af den værdirationelle livsverden gennem de målrationelle systemer, men intrinsisk.

På samme måde går Bourdieu ud fra, stik imod den kendte konsensus/konflikt-diskussion, at dynamik ikke er noget der skal forklares, men er noget som er givet. Enhver social struktur eller praktik er anlagt på at blive afstedkommet og opretholdt under knappe betingelser, hvilket betyder at den kræver en indsats og et stort arbejde at hævdes og opretholdes, hvilket også vil sige reproduceres over tiden $i$ et vekselspil med alle andre agenter og grupper. Enhver praktik definerer situationen og kan alene hævde sig gennem blandt andet at hævde dén definition af situationen mod konkurrerende definitioner af situationen. Det er her begrebet kulturel kapital spiller en væsentlig rolle, præcis som symbolsk kapital i det hele taget. Definitionen af situationen er selv den første indsats i spillet og i kampen om spillet.

Den symbolske repræsentation af virkeligheden er den plads hvor den legitime fremherskende definition af situationen genkendes og anerkendes, hvilket omvendt betyder at dens vilkårlighed miskendes. Det som erkendes og anerkendes som legitimt fordi det er i overensstemmelse med egenlogikken, miskendes i samme øjeblik som ikke alene udformet af egenlogikken, men af interesselogikker inden for feltet som er homologe med og forbundet med andre felters logikker, $i$ særdeleshed det politiske herred ømme (i bred mening) og den sociale og økonomiske dominans.

Heri ligger betydningen af et andet tema hos Bourdieu, kaldet "symbolsk vold" som den typiske måde at fungere for det symbolske og det kulturelle. Med det menes at de symbolske systemer og i særdeleshed den legitime kultur fungerer så de i samme øjeblik de afstedkommer en anerkendelse af deres legitimitet i praktikken, i praksis virkeligg ør miskendelsen af deres vilkårlighed, det vil sige af det faktum at de i deres egen logik er betinget af ikke-symbolsk vold.

Et eksempel: En læseplan præsenterer sig som det optimale udvalg af universelt gyldige kundskaber, om muligt garanteret af videnskabelighed, som gør fordring på at blive undervist i og indlært med kritisk indsigt. I samme øjeblik læreren og eleverne etablerer deres kommunikation på en praktiseret anerkendelse af disse principper, miskender de i praksis at det handler om et vilkårligt udvalg af kundskaber som i sidste instans også er betinget af en mængde faktorer som ikke har noget med kritisk tilegnelse af indsigt at gøre. Dette udvalg er vilkårligt set ud fra principperne for dets egen selvforståelse, men er hverken et produkt af en konspiration eller rent tilfældigt. Det er i sin egen logik opbygget homologt med politiske, sociale og økonomiske logikker, ud over at det er direkte afhængigt af politiske og økonomiske interventioner.

\section{4. Kulturel kapital}

I disse passager af Bourdieu \& Wacquant (1992) definerer Bourdieu ikke økonomisk kapital nærmere. Om kulturel kapital siger han at det bedre kunne kaldes for informationskapital, og minder om at det - som alle andre kapitalformer - eksisterer i tre skikkelser: som inkorporeret (kompetence), som den $\mathrm{d} \varnothing \mathrm{de}$ kapital som er objektiveret arbejde (maskiner) og som den institutionaliserede kapital, det vil sige selve relationen mellem den levende og den $d \varnothing d e$ kapital i selve arbejdsprocessen, $\mathrm{i}$ lønkontrakten og i de juridisk og politisk garanterede produktionsrelationer. 
Med social kapital menes alle de resurser som tilfalder en på grund af ens sociale netværk. Yderligere vigtigt for Bourdieu er hvordan den kulturelle kapital erhverves, gives videre og konverteres til andre kapitalformer.

Bourdieu har hele tiden afvist at det giver mening at komme med begrebsdefinitioner på forhånd. Han mener at begrebets determinationer skal vokse frem af den teoretiske praktik med materialet, deriblandt alle hverdagssproglige, administrative og 'videnskabelige', etablerede anvendelser af begrebet med dets associationer. Men sådan lidt på afstand, bagefter, kan vi i det mindste gøre det lidt lettere for os selv ved at resumere arbejdet med begrebsdefinitionen som for os i en vis grad allerede er gjort af ham. Et eksempel på en sådan sammenfatning er kapitlet om kapitalbegrebet generelt i Broadys afhandling (Broady, 1991, s. 171 - 227). Der gives kapitalbegrebet stor opmærksomhed.

Her vil jeg på min egen måde konstruere en tankegang som jeg mener leder til at Bourdieus begreber kapital og kulturel kapital pludselig falder på plads.

Da jeg siden læste Borudieus artikel mindre kendte artikel om kapitalformerne (1986, jf. ovenfor), opdagede jeg med en vis overraskelse at dette fors $\emptyset \mathrm{g}$ på en forkonstruktion stemte bedre end jeg havde forestillet mig.

En måde at bestemme en vares eller en tjenesteydelses værdi på er at angive dens bytteværdi. Dette forudsætter en rudimentær form for marked hvor varer og tjenesteydelser byttes mod hinanden eller mod det generaliserede tredje, som er penge. Indtil videre kan man tænke sig at det som bevæger nogen til at skaffe sig en sådan vare eller tjenesteydelse ved et bytte, er varens eller tjenesteydelsens brugsværdi for vedkommende. Hvis man viser god vilje, kan man tænke sig at det som regulerer ækvivalensen, er det arbejde som direkte eller indirekte lægges ned i fremstillingen af varen.

På tilsvarende måde kan man tænke sig at agenter eller grupper bytter så at sige sig selv, tilbyder sig selv til hinanden. Da har vi at gøre med sociale relationer. På tilsvarende måde kan vi tale om et marked, sådan som Bourdieu gør det når han taler om det marked hvorpå den sproglige kommunikation udspiller sig (se fx Bourdieu, 1977): udtryk byttes mod udtryk. Men ikke enhver måde at udtrykke sig sprogligt på er lige meget værd på et givet marked. Den som forsøger at deltage $i$ et videnskabeligt symposium med et sprog fra en folkekomedie, har få chancer for at gøre sig hørt, ud over til forsamlingens afkobling. Den som vil komme til orde, må byde på udtryk som er valoriserede af forsamlingen, som genkendes og erkendes som værdifulde i sammenhængen.

I det sædvanlige markedsbegreb som vi kender fra den økonomiske økonomi, byttes lige for lige i princippet. Udvider vi horisonten, ser vi at ikke alle har lige resurser og altså ikke har lige chancer for at producere til et marked, og ikke alle har lige store resurser for at påvirke reglerne for hvad der anses være værdifuldt, det vil sige gøre sine behov for brugsværdien gældende. De der disponerer over kapital, det vil sige levende og dødt arbejde i kombination, er også med til at bestemme hvad der skal findes at bytte, og at der findes noget at bytte. Det vil sige at bag markedets bytte af lige for lige som relation ligger også dominansrelationer.

Noget lignende gælder også for markedet af sproglige ytringer. Kommunikation forudsætter på mange måder at lige byttes for lige. Ellers optræder ingen forståelse. Men samtidig er muligheden for at producere det som for tilfældet er det rette udtryk, ulige fordelt. Og det samme gælder chancen for at være med til at udforme de underforståede regler som fastlægger hvad der for tiden er det rette sprog. Desuden står en sproglig ytring ikke for sig selv. Det er ikke ligegyldigt for ytringens værdi hvem der siger hvad, i hvilken egenskab, det vil sige gennemslagskraft. Det ville ikke hjælpe noget hvis jeg ville erklære at jeg ville lukke SFI, men det ville det hvis samme ytring kom fra ministeren. Men selv i dette selskab kan jeg, som er en indvandrer, ikke gøre mig gældende på samme prægnante måde som mine kolleger som er rigtige danskere, fordi jeg ikke behersker hele det sociale spil som er nedgravet i sproget, og end ikke behersker alment korrekt skoledansk. 
Når man skifter terminologi og taler om felt eller rum hvor agenter på forskellige måder er koblet til hinanden via virksomheder og aktiviteter, som enkeltindivider eller i grupper, så betyder kapital evnen til at gøre sig gældende inden for dette felt eller inden for dette flerdimensionelle rum over for andre deltagere med henblik på virksomheden. Hvilket forudsætter at min ytring bliver genkendt og anerkendt som værdifuld i sammenhængen.

Virksomhedens art definierer positioner. Til disse positioner svarer dispositioner til at udøve den praktik som passer til positionen. En ytring som gør sig gældende, kan kun frembringes af nogen med samme dispositioner. Men hverken virksomheden eller dens positioner er givet en gang for alle, men er netop en bevægelig resultant.

Unægtelig findes her hos Bourdieu en slags grundantagelse om at sociale relationer altid og overalt er magtrelationer i den mening at det er et spørgsmål om at gøre sig gældende over for hinanden med henblik på virksomheden, og at de i den mening altid forhandler herredømme i interessens navn. Samtidig er han meget klar over at dette meget vel kan tage form af en altruistisk kærlighed til næsten: Det afhænger helt af hvilket felt vi har at gøre med.

Kapital har altså mere at gøre med evnen til at producere til et marked, at producere ytringen inden for en virksomhed inden for et felt, at forholde sig inden for et socialt rum, end at det alene skulle sigte mod selve de bytte- eller domiansrelationer som også er forudsat.

\section{Men hvad betyder så kulturel kapital?}

Vi taler om kulturel kapital. Hvad betyder så kulturel kapital i denne sammenhæng? Det betyder ikke det som det gerne betyder i en filosofisk antropologi hvor kultur stilles mod natur. Vi studerer sociale fænomener og i den mening er alt vi studerer, kultur. Hos Bourdieu er der tale om kultur i en snævrere mening, nemlig den side af den menneskelige virksomhed som er symbolsk. Tilspidset kunne man sige: som arbejder med ord (Broady, 1991, s. 173). En side af hele den menneskelige virksomhed er at den symbolske repræsentation af virkeligheden skyder sig ind mellem mennesket og virkeligheden. Vi er symboliserende dyr bortset fra at vi er sociale dyr, som Aristoteles sagde. Evnen til symbolsk repræsentation ledsager enhver virksomhed for så vidt som den er menneskelig: Lige meget om vi snedkererer et bord, sælger aktier, opfostrer børn eller holder forelæsninger. Men den har den iboende mulighed at selvstændiggøre sig når selve den virksomhed der er tale om, er at symbolsk repræsentere virkeligheden, at arbejde med symboler, at være koblet til hinanden i denne omgang med symboler. Det er det Bourdieu kalder for det symbolske område.

Det der menes med det kulturelle, opfattes af Bourdieu som en slags underafdeling af dette symbolske område. Der er tale om yderligere en uddifferentiering og selvstændiggørelse som Bourdieu forbinder med opkomsten af skrivekunsten og det formelle uddannelsessystem. At virke pr. symbol ændrer karakter når den tilsvarende kompetence ikke kun findes i forkropsliggjort form, men også objektiveres i produkter og kan akkumuleres også i produkter, og når reproduktionen af den kompetence bliver formelt institutionaliseret som kompetence til at begå denne akkumulerede og objektiverede kompetence.

Bourdieu har hele tiden i forbindelse med sine antropologiske studier af et præmoderne samfund hos kabylerne i Algeriet på den ene side og studier af det moderne franske samfund på den anden stærkt markeret den forskydning fra det symbolske som et generelt fænomen som ledsager al virksomhed, til udviklingen af den forkropsliggjorte, objektiverede og institutionaliserede kompetence som et selvstændigt domæne. At være kultiveret betyder da at have aflagt eksamener, kunne håndtere bøger, være bærer af en garanteret titel. At eje kulturel kapital betyder ikke bare at eje alle disse objektiverede og institutionaliserede kapitalformer, men i første omgang at eje evnen til at skaffe sig dem og at eje evnen til at håndtere dem, at bevæge sig med dem, at lade dem virke. 
Broady foreslår oversættelsen "dannelseskapital" ("bildningskapital", Broady, 1991, s. 174), hvilket jeg ikke synes er så vellykket på grund af den moderne modstilling af kultur eller civilisation og dannelse i von Humboldts ånd, som selv Broady signalerer. Det er formodentlig bedre med Bourdieu selv at henvise til alternativet "informationskapital" hvis man dermed mener at kunne håndtere og disponere over alt det der behøves for at i alle relevante situationer vide hvordan man bærer sig ad med symboler.

Vi skal dog hele tiden huske på at denne kapital ikke gælder for sig selv, men kun i relation til et marked eller et felt hvor det gælder for øjeblikket, og i relation til givne positioner inden for dette felt. Hvilket betyder at denne kan miste eller $\varnothing$ ge sin værdi, eller ved behov kan konverteres til anden kapital. Broady giver her et eksempel hvor nogen arver en betydelig kulturel kapital (det vil sige får det forærende på grund af sin herkomst fra en kultiveret familie), og på den måde får meget lettere ved at skaffe sig en formel uddannelse, og på baggrund af begge dele får endnu lettere ved at skaffe sig en $h ø j l \emptyset n$.

En anden ting som umiddelbart må klargøres, er at kulturel kapital ikke har noget at gøre med reelle konkrete tekniske kompetencer i det pågældende, undtagen hvis selv sådanne indgår i de krav som stilles af feltet.

Her kan man på en frugtbar måde gå ud fra enkle resultater af observationsstudier af klasseværelse-undervisning. Det kan vises at de elever som har de bedste skoleresultater, ikke nødvendigvis - men det kan heller ikke udelukkes - har bedre realkundskaber i det der eksamineres i, men er bedre til at håndtere selve deres forhold til hele situationen. Og eftersom begge dele spiller en rolle, kan man konvertere sin kulturelle kapital til en bonus, tilsyneladende (eller reelt) selv $\mathrm{i}$ indlæringshenseende i snæver mening. Det betyder naturligvis ikke at disse elever ikke har lært sig noget, men snarere at de kan alt det som hører til: i den mening er de dygtigere end andre i forhold til skolens og samfundets definition af excellency. Dette spiller en stedse større rolle i forhold til om netop excellency defineres i større eller mindre grad som reel kunnen af de definerede kundskaber, eller som en drevenhed til at opvise selv de underforståede egenskaber som præmieres.

Som en illustration af hvad dette kan omfatte, kan vi med Broady henvise til Homo Academicus (Bourdieu, 1984/1988), Bourdieus studie af universitetsprofessorer, hvor professorerne kategoriseres i forhold til om deres kulturelle kapital hovedsagelig består af universitetsorganisatorisk kapital, videnskabsorganisatorisk kapital, rent videnskabelig kapital, alment intellektuel kapital, respektive kapital knyttet direkte til den økonomiske og/eller den politiske sfære.

Det sidste er forresten et typisk tilfælde af kapital-konvertering: Inden for teknologi, handel, jura og medicin er der en type professorer som har deres universitetsmæssige kompetence fra den rolle de spiller i det politiske og $\varnothing$ konomiske etablissement, både privat og offentligt. Hvilket siger meget mere om universitetet end det man plejer at klage over, nemlig deres ekstra-indkomster.

\section{Hvad kan begrebet kulturel kapital og teorien omkring det bruges til?}

Det enkleste er nok at gå direkte til Bourdieus senere store empiriske unders øgelser som fx La Distinction (1979/1984; social struktur og livsform/smag), Homo Academicus (1984/1988; social struktur og uddannelsessystemets struktur belyst ud fra professorerne), La noblesse d'état (1989/1996; "statsadelen": social struktur og de universitære eliteskoler), Les régles de l'art (1992/1996; "kunstens regler", social struktur og den litterære institution).

I alle disse studier udvikler og benytter Bourdieu en måde at teoretisk konstruere det han kalder "det sociale flerdimensionelle rum", en konstruktion jeg ovenfor har kaldt "social struktur", og som er hans egensindige måde at skaffe sig et redskab som hos andre sociologer tager formen af en klasseanalyse eller en stratificeringsanalyse. Han er nok ikke den eneste der er ganske træt af 
debatten omkring disse mere klassiske analyser, men han er en af dem der har fors $\emptyset$ gt at gå andre veje, både metodisk med den såkaldte korrespondensanalyse og teoretisk.

I alle disse studier konstruere han det sociale rum som et system af kinesiske æsker hvor en homolog struktur gentager sig på hvert niveau, men i transformeret form: Først det sociale rum i sin helhed, siden hvad vi kunne kalde for overklassen og de tilknyttede lags rum, siden det kulturelle rum, siden det litterære rum, og så videre.

Den konstruktion som gentager sig, er en opstilling af rummet af sociale relationer mellem grupper efter et antal dimensioner, især to, en vertikal og en horisontal akse. Den grafiske fremstilling er et produkt af den underliggende korrespondensanalyse som tænker og fremstiller forskelle i relationer som distancer. Og i hvert tilfælde benytter Bourdieu sig af en polarisering af på den ene side den kulturelle kapital og på den anden side den økonomiske kapital som yderpositioner på den horisontale akse.

Meget forenklet kan man sige at denne måde at arbejde på blandt andet viser ikke bare, så at sige, strukturelle og kvantitative forskelle i besiddelsen af kapital i det hele taget - på den vertikale akse placeres alt fra overklassen $\varnothing$ verst til arbejderklassen nederst - men samtidig synliggøres horisontale differentieringer mellem positioner som bygger på besiddelsen af kapital af kulturel respektive økonomisk karakter. I dette tilfælde for eksempel i form af modsætningen mellem fraktioner inden for overklassen som er næringslivets toppe respektive universiteternes, eliteskolernes og forskningens toppe. Eller mellem skolelærere og bibliotekarer på den ene side og på den anden side små selvstændige næringsdrivende. Eller blandt universitetsprofessorerne mellem de rent videnskabeligt orienterede professorer inden for naturvidenskab og humaniora respektive professorerne inden for jura, medicin og teknologi som især er forankret i den politisk-økonomiske sfære.

Det som er mindre banalt end denne konstruktion, er om en sådan konstruktion kan forklare specifikke træk i de respektive sociale praktikkers egenlogik, eller i de respektive kulturelle virksomheders egenlogik.

En anden side af metoden som kan være spændende, er at den tillader et udskillende overblik over samspillet mellem for eksempel social og regional herkomst, $k \emptyset n$, alder, nuværende social placering, arvet social kapital, erhvervet formel uddannelse, familiesituation, boligkvarter, karriere, videnskabelige og politiske standpunkter, indkomst og formue osv. osv.

Korrespondensanalysen og dens grafiske fremstilling synliggør hvilke dimensioner man kan få frem, som opsamler et maksimalt volum af samspil af alle disse faktorer. Bourdieu hævder da at i alle disse studier spiller polariseringen mellem forskellige kapitalformer, først og fremmest kulturel kapital på den ene side og politisk-økonomisk kapital på den anden side, en central rolle som underliggende logik i det sociale spil.

Hvis man vil se metoden og teorien anvendt i Skandinavien, kan man se på Donald Broady \& Mikael Palmes studier af populationen af universitetsstudenter i Sverige eller af gymnasierne i Stockholms bedrestillede forstæder (jf. Palme, 2008). ${ }^{1}$

Selv synes jeg at man måske burde se nærmere på den type af analyser inden man går videre med de nyeste mode-analyser af typen 'det postindustrielle samfund er et informations-

/uddannelsessamfund' eller af typen 'de intellektuelle udgør den nye overklasse' eller af typen 'vi skal uddanne os ud af arbejdsløsheden', efter at tanken om at man skal bortreformere klassesamfundet ved hjælp af skolen $\mathrm{i}$ al stilhed er forsvundet fra horisonten.

Man kan jo også have glæde af Bourdieus approach i meget mere håndfaste sammenhænge. På embedets vegne er jeg tvunget til at læse en masse litteratur om individuel og social forrentning af

1I 2008 forsvarede Mikael Palme sin svenske doktorafhandling. Heri findes bl.a. tekster af Palme og Broady som afrapporterer de undersøgelser der henvises til i denne artikel (red. anm.). 
investering i uddannelse, og da bliver jeg til min forbløffelse hele tiden konfronteret med en mere eller mindre underforstået teori om at der er en teknisk sammenhæng mellem formel uddannelseseksamen, produktivitet, indkomst og individuel og social velfærd, selv i samfund med en hovedsageligt agrar subsistens $\varnothing$ konomi. Man behøver ikke have læst Bourdieu for at formode at dette må være galt. Men hvis man har læst Bourdieu, kan man bedre klargøre hvorfor det er galt, og hvorfra det kommer. Meget groft sagt: Der er sikkert en sammenhæng mellem formel uddannelse og Iøn, men sandsynligvis formidles denne sammenhæng ikke af produktivitetsstigninger, men af en forrentning af kulturel kapital, hvilket er noget helt andet (jf. Gesser, 1990).

\section{Udviklingen af begrebet kulturel kapital i Bourdieus forfatterskab}

Når man studerer fremkomsten af begrebet i Bourdieus forfatterskab, sådan som fx Broady gør det (jf. Broady, 1991), kan man opdage visse ting.

Bourdieus første studier handler om præmoderne samfund i overgang i Algeriet. Som så mange andre måtte Bourdieu da slås med alle de problemer der opstår når man opdager at der i disse samfund, fremfor alt i en mere rendyrket udformning som man i enkelte tilfælde stadig kan observere, ikke eksisterer en økonomisk økonomi, det vil sige økonomi opfattet som et selvstændigt og tilsyneladende også reelt delsystem i den samfundsmæssige helhed som fungerer ifølge en selvstændig logik, sådan som den videnskabelige diciplin "økonomi" i moderne samfund opfatter produktion, fordeling og forbrug af livsforn $\varnothing$ denheder og tjenesteydelser. Skønt man naturligvis lever og reproducerer livet. Og desuden, og her skiller Bourdieu sig måske fra en del romantiserende antropologi, at der også her findes en underliggende økonomisk økonomi, om end af en anden type og frem for alt med en helt anden måde at kombinere denne økonomiske økonomi med alle andre sfærer i samfundet, først og fremmest det politiske herredømme, slægtskabet, sædvaneretten og religionen. Og endelig det man kan kalde det symbolske system som udgør en slags net som spænder over alle disse sfærer, fordi de alle fungerer pr. symboliserede forestillinge og motivationer som kommer imellem når materialiserede praktikker af stofskiftet med naturen og sociale relationer danner sig, og som i en vis grad kan komme til at leve deres eget liv, for eksempel når det bliver nedfældet i sproget, i handlingsm ønstre, i praktiserede kodificeringer eller i mere elle mindre indenlandske lærde fortolkninger osv.

Det som på et tidligt stadium fascinerer Bourdieu, er ikke bare hvordan man skal forstå indvirkningen af disse trosforestillinger og bevæggrunde på selve den adfærd som materialiserer sig, så snart man går ud fra at dette ikke kan opfattes som rent kausale kæder, men i stedet som handlingssekvenser styret af indsigt og grunde. Han er først og fremmest fascineret af det specifikke i det præmoderne samfund, både når det gælder indholdet i disse forestillinger og motiver, og når det gælder måden hvorpå de er kombineret med selve handlingerne som materialiserer sig. Det vil sige: Det symbolske systems indvirkning er en anden fordi det har et andet indhold og betydning og virker på en anden måde.

Noget lignende kommer frem når Bourdieu, præcis som Habermas senere gør det, studerer Webers religionssociologi snarere end hans $\varnothing$ konomiske sociologi, og opdager hvordan Weber tilskriver det symbolske system (i dette tilfælde den protestantiske etos) en anden rolle ved etableringen af kapitalismen end ved funktionen af den etablerede kapitalisme.

Man kunne illustrere dette når man ser hvilken rolle kvæg spiller i de såkaldt primitive samfund. Kvæg er ikke en vare som byttes eller sælges eller konsumeres som mad. De er snarere medlemmer af bosættelsen og bærere af det vi kalder religiøst-rituelle relationer mellem de synlige og usynlige medlemmer. Når kvæget ved store højtider slagtes og konsumeres, opretholdes derved sammenholdet både horisontalt og vertikalt. Samtidig er det faktisk sådan at systemet også 
garanterer at alle med jævne mellemrum spiser sig mætte i festmad, og at den ligelige fordeling af rigdommen som forhindrer den enkeltes akkumulation på bekostning af andre, sættes i værk. Det vil sige at kvæget på samme tid er hellige dyr og rigdomme, selv i økonomisk- $\varnothing$ konomisk mening. Men den indlejring af den $\varnothing$ konomiske $\varnothing$ konomi i en $\varnothing$ konomi af gratis gaver og rituelle fester forhindrer den $\varnothing$ konomiske $\varnothing$ konomi i at fremtræde som sådan. Når, i overgangsperioder, deltagere i festen som ikke kan deltage, beder om at få deres andel i penge, betragtes de som tyve. Derimod kommer det puritanske etos til at legitimere den kapitalistiske virksomheds gevinster som fremtræder fuldt synlige, som en bekræftelse på en guddommelig prædestination, mens den fuldt etablerede kapitalisme kommer til at betragte alle moralske eller religiøse overvejelser omkring profit som irrelevante.

Det spørgsmål som optager Bourdieu, er dette: Hvis vi analytisk, ud fra vores betragtelsesmåde skelner mellem den økonomiske økonomi og det symbolske system, hvilke relationer, hvilke kombinationer findes der da mellem disse to? Og det afgørende spørgsmål bliver: Hvordan ser den interne $\varnothing$ konomi af de symbolske praktikker ud, og hvordan er den relateret til en interne økonomi af $\varnothing$ konomiske praktikker?

Det vil sige: Selv når de forskellige sfærer både ideelt og reelt uddifferentierer sig, så findes de stadig med alle sammen. Og alle har sin egen økonomi, sin egen husholdningslogik, såvel videnskab som kunst, religion, sprog, slægtskab osv. Og de er alle artikulerede på hinanden på en specifik måde. Og i alle typer af samfund er $\varnothing$ konomien af det symbolske afhængig af $\varnothing$ konomiens og politikkens $\varnothing$ konomi, selv i uddifferentierede samfund.

Men det som i den forbindelse interesserer Bourdieu mest - fordi han trods alt primært er det vi kunne kalde for en kultursociolog - er ikke at kirken også har en økonomi, eller at forskellige sociale klassers $\emptyset$ konomiske interesser slår igennem respektive direkte intervenerer i kirkens budskab, organisation og teologi. Det som interesserer ham mest, er hvordan religionens egenlogik, også hvor den etablerer sig som selvstændig og respekteres som sådan, inden for sit eget område bærer på spor af sin artikulation på andre logikker, og lægger sin egen vægt i vægtskålen i termer af de sammenfattede sociale styrkeforhold. Med andre ord: Symbolsk vold spiller en central rolle i den sociale og den kulturelle reproduktion. Forholdet mellem gud og menneske, mellem præst og lægmand, mellem det religiøse og det profane, som forestilling/motiv og praksis, er med til at forstærke forholdet mellem kapital og arbejde. Det vil sige at man ikke kan gøre som Habermas gør, tage den moderne uddifferentiering helt på ordet, eller bare klage over systemverdenens indtrængen på livsverdenen. Livsverdenen selv konstituerer sig som en kombineret interesselogik, og en overgribende klassehabitus er det generative princip som fungerer som 'omdrejningspunkt'. Det som Weber kaldte for legitimation, er ikke bare en legitimation af noget andet som gør det legitimt. Det gør det også stærkere i sin egen ret.

Når Bourdieu i Kabylien, hvor en primitiv økonomi allerede er kombineret med hvad vi forsimplet kunne kalde for feudale indslag, ser hvordan "en mand af ære" samler på "ære" med praktikker som alle er af symbolsk karakter, alt fra hans måde at aldrig tabe beherskelsen, til hans måde at skride over gulvet, til gaver, fester, via giftermål og alliancer, så kan han konstatere at han bliver rig i alle henseender, opererer med en gennemslagskraft på alle områder hvor hans symbolske mesterskab i stadig at håndtere æren udelelig, er en del af hans rigdom. Han disponerer over en 'startkapital', siger Bourdieu (for referencer, se Broady, 1991, s. 185). Det vil sige inden han overhovedet begynder på at gøre forretninger, disponerer han over en symbolsk kapital som på ingen måde har med forretninger at gøre, men som betyder en hel del for hans forretninger. Det er ikke at han har prestige, relationer og savoir faire i forretninger. Han er i det hele taget en mand af ære, ikke en forretningsmand. Men af de årsager gør han også gode forretninger, ville vi sige. Men bare en antydning som denne er en bespottelse af dette symbolske system. Bourdieu er meget optaget af at finde ud af hvordan sådanne delte trosforestillinger og motiver som er symbolske sociale relationer, 
opstår og vedligeholdes. De ligger nemlig ikke i hovedet på folk, men de udøves som sociale relationer. Det er dét socialisation betyder, i det mindste i den oprindelige betydning af begrebet "socialisation": Samfundsgørelse; ikke individuel internalisering af normer eller indlæring af adfærdsmønstre, men konstitueringen af socialitet.

Begrebet kulturel kapital udformes når man spørger hvilken 'startkapital' børnene fra forskellige sociale klasser i et moderne samfund med et separat apparat til sekundær socialisation og formel uddannelse med uddannelsestitler garanteret af det centrale statsapparat på samme måde som statsobligationer, fører med sig som udgangspunkt for deres deltagelse i den proces, og i deres påfølgende karriere uden for uddannelsessystemet. Da taler vi om 'startkapital' som også noget der ligger før 'skole-forretninger', og som på samme måde principielt ikke har med skolens meritokratiske selvforståelse at gøre. Nå man mere specielt interesserer sig for koblingen mellem familie og social klasse (som tilsammen erstatter det som slægten var i det primitive samfund) og for intergenerationel reproduktion, kan man tale om kulturel arv som et aspekt af den kulturelle kapital.

Her henvises til en anden tekst på engelsk (Bourdieu \& Passeron, 1977). Det handler om forskelle i udgangssituation som er bestandige i processen, i og med at det praktiske og det symbolske mesterskab af kulturteknikker og den legitime kultur erhverves gratis gennem livet i familien før og ved siden af skolen, og det handler om hvordan skolen i stor udstrækning bygger på og forstærker disse forskelle. Som uddifferentieret sfære gør skolen fordring på at fungere efter en meritokratisk logik, uanset at den naturligvis har en $\emptyset$ konomi og indirekte er underlagt det politiske regi. Men den egenlogik er samtidig et marked eller et felt hvor den kulturelle startkapital som børn fra visse lag har fået gratis, har højere værdi end andre typer af forudsætninger, inklusive den del af den kulturelle kapital som vi kan kalde uddannelseskapital i snæver mening, og som vi da måler med et antal generationers formelle uddannelsestitler både på fædrene og mødrene side. Allerede fra begyndelsen anvendes begrebet også for at empirisk kunne belyse denne faktors gennemslagskraft for børnenes skolekarriere, uafhængig af forældrenes formue og indkomst i snævrere økonomisk mening, eller deres sociale placering generelt.

Som vi ved, har den uddannelsessociologiske diskussion siden 1970-tallet næsten udelukkende handlet om hvorvidt uddannelsessystemets interne marked og allokeringsfunktion for arbejdskraftmarkedet, jobstrukturen, indkomststrukturen og den sociale struktur har haft positive eller negative effekter på forskellige faser af den sociale differentiering de seneste 100 år. Bourdieus position i den diskussion er næsten altid blevet misforstået fordi den for det meste har været reduceret til at man har tilskrevet ham en social-deterministisk eller kultur-deterministisk reproduktionsteori som en variant af en neomarxistisk $ø$ konomi-deterministisk reproduktionsteori, eller underligt nok som dennes modpol.

En af de mere spændede ting ved Bourdieus syn på kulturel kapital er at den opfattes dels primært som en inkorporeret kompetence/handlingsorientering, dels som en relationel størrelse. Det vil sige: den eksisterer kun i relation til et marked/felt/rum hvor komptetencen/orienteringen gælder.

De dispositioner som habitus-begrebet begrebsligg ør, eksisterer alene som dispositioner til handling i visse objektive omgivelser, og er selv et produkt af disse omgivelser. At ikke alene praktisk kunne håndtere logikken i hele skole-virksomheden, men også at symbolsk beherske den, det vil sige bevidst forholde sig til den i stedet for bare at være underlagt den, er noget som alene er noget på grund af at det er en kompetence til at spille et spil som findes, relativt uafhængigt af hvad de enkelte aktører for $\varnothing$ jeblikket ved og vil. Men dispositionen er i sidste omgang også formet af dette spil. Den kognitive og motivationelle førbevidste handlingsorientering udgør en inkorporeret omsættelse af de til rådighed stående handlingsmuligheder. Eller som Bourdieu ofte siger: At gøre en dyd af nødvendigheden. 
Kulturel arv forudsætter at de dispositioner man fik gratis, er de dispositioner som passer for at kunne udøve de positioner som er indskrevne i en objektiv struktur. Men objektiv ikke som naturlige forhold, men som inkorporeret og determineret (af omgivelserne) og kausalt determinerende for adfærden. Bourdieu er ikke bare en student af Durkheim, som han fundamentalt kritiserer sammen med strukturalismen, men også af Weber og af de ikke-transcendental-idealistiske eller eksistentialistiske fænomenologer. Samt naturligvis af selektivt valgte Marx-tekster.

\section{Bourdieus egen fremstilling $i$ "The Forms of Capital" (1986)}

Vi skal senere gå ind på indhold og betydning af begrebet kapital, særligt kulturel kapital, gennem at se på hvordan begrebet anvendes eller snarere udformes som et redskab i gennemførelsen af konkrete undersøgelser. Men man kan også få hjælp af lidt mere farlige, oversigtlige, så at sige statiske og litterære præsentationer. Bourdieu har selv skrevet en sådan som har haft ganske lille opmærksomhed, måske fordi den ikke findes publiceret på fransk, og fordi den oprindelige publikation på tysk (Bourdieu, 1983) var svært tilgængelig.

Hvis vi går til den engelske udgave af teksten (Bourdieu, 1986), så får vi i resume følgende: Den sociale verden er akkumuleret historie. Det væsentlige ved den er at der stadigt laves historie, men ikke tilfældigt eller efter behag, men i forlængelse af den akkumulerede historie som har sin inerti. Kapital er det begreb som udtrykker den forhåndenværende akkumulation over hele det sociale felt. Kapital er akkumuleret socialt arbejde (ikke bare i produktionen), enten i forkropsliggjort form som kompetence eller i materialiseret form. Den som tilegner sig akkumuleret kapital, tilegner sig eventuelt eksklusivt, eventuelt på bekostning af andre - social energi i en monopolstilling.

Den sociale energi tilegnet på den måde, har sin egen indbyggede dynamik (vis insita) og sin egen indbyggede lov (lex insita) som tilsammen underbygger de observerbare regelmæssigheder i den sociale verden. Dette gør at de sociale spil som udgør den sociale verden, ikke kan spilles på den måde man netop nu skulle finde på, bevidst og viljemæssigt, uden inerti, uden forudgående akkumulation, uden arv eller erhvervede egenskaber. Det tager tid at akkumulere kapital og akkumulationen fungerer med indbyggede mekanismer som tenderer mod at reproducere sig $\mathrm{i}$ samme eller udvidet form. På den baggrund er, for de aktuelle handlinger, ikke alt muligt på samme måde i samme grad; visse ting er mere sandsynlige end andre. Derfor angiver strukturen af fordelingen af forskellige former for kapital på et givet tidspunkt også strukturen af den sociale verden, det vil sige de objektive strukturer som er de begrænsninger som omgærder sociale praktikkers chancer for at vellykket gennemføres.

Den moderne selvforståelse som kommer til systematisk udtryk i den $\emptyset$ konomiske teori, har fremtvunget en fremstilling af denne praktikkernes $\varnothing$ konomi som opdelt i to sfærer: den sfære af den $\emptyset$ konomiske praktik som er objektivt og subjektivt orienteret mod profitmaksimering, det vil sige en $\varnothing$ konomisk form for egen-interesse, og har dermed defineret alle andre sfærer som ikke-økonomiske og ikke defineret af egen-interesse. På denne måde bortdefineres det faktum at egen-interesssen $\mathrm{i}$ de andre sfærer, som er en forvandling (transsubstantiation) af egen-interessen, ikke fremstår som sådan, men som interesse-fri: Økonomisk kapital forvandles til kulturel kapital eller til social kapital, materiel kapital forvandles til immateriel kapital. Den økonomiske kapital konstituererer sig sammen med kunst for kunstens skyld eller den rene teori. Den sociale anerkendelse af den $\varnothing$ konomiske interesse producerer miskendelsen af interessen i de andre sfærer, men selv det har også sin pris. Den forvandlingsproces eller den "sociale magi" som Bourdieu kalder det i andre sammenhænge, sker til prisen af et enormt okkultationsarbejde som skjuler det som en praktikkernes økonomi vil rekonstruere, nemlig den konstante omsætning mellem forskellige former af kapital eller magt som sætter sig igennem i den sociale verden, som tilsyneladende består af uddifferentierede sfærer med 
hver sin egenlogik, defineret som materielt interesseret respektive immaterielt fri af verdslige interesser.

I Bourdieu (1986) gentages opdelingen mellem kulturel kapital i inkorporeret form (varige dispositioner), i objektiveret form og i institutionaliseret form. Det sidste bliver her ligestillet med formelle uddannelsestitler. Her minder han om at han har udformet begrebet for at kunne forklare forskelle i erobringen af formelle uddannelsestitler på et akademiske marked hos børn som kommer fra forskellige sociale klasser og fraktioner, gennem at relatere disse forskelle til forskelle i de respektive klassers besiddelse af kulturel kapital.

Den arbejdshypotese bryder med både den spontane begavelsesideologi og human capitalteorien. Fejlen med human capital-teorien er blandt andet at den forsøger at forstå relationen mellem investering i og afkast af uddannelse gennem at relatere det til forskellige markeder, men gør det som om det hele er et spørgsmål udelukkende om økonomiske faktorer. Derved glemmer man at både på investeringssiden og på markedssiden er det et spørgsmål om ikke bare økonomiske resurser og indsatser, men lige så meget eller mere om kulturelle og sociale. Den vigtigste faktor er transmissionen af kulturel kapital i de familiale omgivelser. Sagt på en anden måde: Begavelse eller evne er selv et produkt af et enormt arbejde over en længere tid i familien, og af en bekræftelse og forstærkning heraf i det formelle uddannelsessystem.

Desuden må man tage med i beregningen at kulturel kapital fungerer som inkorporeret orientering, hvilket forudsætter tid og energi langt tilbage i slægten og i den enkeltes liv før skolegangen, forudsætter et etos som gør en tilbøjelig til disse investeringer, og forudsætter resurser og livsvilkår som gør opkomsten og opretholdelsen af et sådant etos muligt og sandsynligt. Denne transmission af rigdom kan ikke foregå i form af penge, formue og end ikke som titler, gennem gaver, lån, $k \emptyset b$ eller bytte. Disse dispositioner kan ikke købes sammen med arbejdskraften eller koncentreres uden at hele systemet for $k \varnothing b$ af arbejdskraft trues af at blive sat ud af spillet.

Erhvervelsen af disse dispositioner er stærkt forbundet med den enkeltes biologiske egenskaber og første opvækstvilkår, og forudsætter ikke nødvendigvis en bevidst indprentning. Det gør at sammenblandingen af arv og præstation okkulteres. Erhvervelsens distinktive kendetegn tenderer mod at være vældigt upåfaldende og tilsyneladende uvæsentlige karakteristika som for eksempel en accent i sproget eller en måde at gå på.

Dette medfører at den kulturelle kapital også tenderer mod at fungere på en symbolsk måde, det vil sige miskendt som kapital, men anerkendt som en legitim kompetence. Den kulturelle kapital får sin gennemslagskraft ikke for hvad den er, en distinktiv markering som bygger på forskellige former af kapitalbesiddelse, og som giver adgang forskellige former af kapital, men som en legitim kompetence til at udøve en praktik. Ved ulige fordeling af alle resurser, inklusive de kulturelle, får besiddelsen af kulturel kapital på et marked kendetegnet ved knaphed allerede af denne årsag en skel-sættende værdi.

Knaphed er ikke en naturtilstand på dette marked, men den generes af den ulige fordeling af relevante resurser og af selve konkurrencen om disse resurser. Det er den ulige fordeling som gør kapital til kapital, det vil sige gør kapital til noget som har skel-sættende effekter, og som udgør rammebetingelserne for konkurrencen, det vil sige den logik som råder over feltet, og ifølge hvilken der skal konkurreres.

Men den mekanisme som er den stærkeste trumf i systemet, er selve vilkårene for transmission og tilegnelse af inkorporeret kapital som sker implicit og grundlæggende i den første familiale socialisering. Det gør at den okkulteres af sig selv, og at alle fors $\varnothing \mathrm{g}$ på at indhente et efterslæb selv slæber efter, hvis man regner alle de kompensationer som skulle behøves, ud.

Objektiverede kulturelle goder kan tilsyneladende transmitteres og erhverves lettere, men dette er et skin der bedrager. For hvis man ser bort fra deres rent materielle eksistens og erhvervelse, eksisterer de faktisk kun i relation til inkorporeret kulturel kapital som er vejledningen i deres 
legitime anvendelse som man må anskaffe sig i persona eller per prokuration. Dette betemmer den særlige, ambivalente status af det såkaldte kadre-personale, eller i andre henseender af kulturarbejdere eller de intellektuelle blandt dem.

For Bourdieu er den tredje form for kulturel kapital, nemlig den institutionaliserede, særligt vigtig fordi den har at gøre med de formelle titler, forlenet af det formelle uddannelsessystem og garanteret af staten. Den lovligt beskyttede eksamenstitel har virkning helt af sig selv, i sin egen sfære uafhængig af bærerens person eller tilmed af hans erhvervede kulturelle kapital. Den sociale alkymi som selve autoriseringen af en autoriseret læge (og tilsvarende) indebærer, fungerer på en relativt selvstændig måde. Den gennemslagskraft findes ikke hos den autodidakte eller den amat $\varnothing r$ som reelt har skaffet sig den tilhørende kulturelle kapital. Den mest karikerede manifestation af dette faktum finder vi i rekrutteringen til uddannelsestitler eller positioner gennem en rangordningseksamen (concours) hvor den infinitesimale forskel mellem den sidst antagne og den først afviste kandidat ikke desto mindre gør dem til to helt forskellige kategorier af mennesker for resten af livet. Her har vi at gøre med en speciel mekanisme, institueringen som en måde at så at sige automatisk skabe selve den sociale erkendelse af det som fremstår som kompetence, ud af ingenting andet end selve forlængelsen af titlen som sådan.

På den måde bliver ikke alene titlen, men selv dens økonomiske værdi både sammenlignelig og som regel garanteret, hvilket skaber et separat, beskyttet arbejdskraftmarked og lønfastsættelse som nu definitivt er helt undtaget den relation mellem uddannelseskvalifikation, produktivitet og indkomst som antages inden for human capital-teorien.

I La noblesse d'état (Bourdieu, 1989, engelsk oversættelse 1996) om de franske universitære eliteskoler har Bourdieu insisteret kraftigt på det faktum at opkomsten af den moderne stat og opkomsten af et korps af legitimerede embedsmænd, akademiske discipliner såsom medicin, jura, læreruddannelser og embedseksamener, er en og samme proces.

Afslutningsvis insisterer artiklen (Bourdieu, 1986) også på de tre kapitalformers konverterbarhed. Al kapital i bred mening er socialt arbejde i bred mening, det vil sige tid og social energi. Det vil sige at det som koster på den ene konto, giver afkast på den anden konto, men ingenting er gratis og summen er konstant. Hvilket også betyder at man kan studere forskellige sociale klasser og fraktioner, eller for den sags skyld individer, ud fra deres strategier i forhold til forskellige typer af kapital som den skiftende base for deres muligheder for at hævde sig.

De typiske muligheder der er for at erhverve, arve, $k \varnothing b e$, forhandle sig til forskellige former af kapital, kombineret med de typiske muligheder der er for at de legitimeres/okkulteres, i kombination med styrkeforholdene på markedet for alle kapitalgoder tilsammen, giver en baggrund for at for eksempel forstå forskellige klassers tilbøjelighed til at satse på uddannelsestitler.

Alt dette er noget helt andet end at postulere at uddannelsessystemets udvikling i termer af søgningen til uddannelse, strukturforandringer og effekter kan forklares med forandringer i arbejdskraftens tekniske eller sociale kvalifikationsbehov udledt af den teknologiske eller $\varnothing$ konomiske udvikling. 


\section{Referencer}

Bourdieu, P. (1979). La distinction. Critique sociale du jugement. Éditions de Minuit, Paris. På engelsk som: Bourdieu, P. (1984). Distinction. Social Critique of the Judgement of Taste. Routledge and Kegan Paul: London.

Bourdieu, P. (1983). "Ökonomisches Kapital, kulturelles Kapital, soziales Kapital". I: Kreckel, R. (red.), Soziale Ungleichheiten (Soziale Welt, Sonderband 2), Göttingen, s. 183-198. På engelsk som: Bourdieu, P. (1986). " The Forms of Capital". I: J.G. Richardson (red.). Handbook of Theory and Research in the Sociology of Education. New York \& London: Greenwood Press, s. 241-258.

Bourdieu, P. (1984): Homo Academicus. Paris: Éditions de Minuit. På engelsk som: Bourdieu, P. (1988). Homo Academicus. London: Polity Press.

Bourdieu, P. (1989). La noblesse d'état: grande écoles et ésprit de corps. Paris: Les Éditions de Minuit. På engelsk som: Bourdieu, P. (1996). State Nobility. Elite Schools in the Field of Power. Cambridge: Polity Press.

Bourdieu, P. (1992). Les règles de l'art: genèse et structure du champ littéraire. Éditions du Seuil, Paris. På engelsk som: The Rules of Art : Genesis and Structure of the Literary Field.

Bourdieu, P. (1996). The rules of art: genesis and structure of the literary field. Polity Press: Cambridge.

Bourdieu, P. (1977). The Economics of Linguistic Exchange. Social Science Information. 16(6), s. 645668.

Bourdieu, P. et al. (res.)(1993). La misère du monde. Éditions du Seuil: Paris. På engelsk som: Bourdieu, P. et al. (eds.)(1996). The Weight of the World. Polity Press: London.

Bourdieu, P. \& Wacquant, J-C. (1992). An Invitation to a Reflexive Sociology. Polity Press: Cambridge.

Bourdieu, P. \& Passeron, J-C. (1970). La reproduction. éléments pour une théorie de système d'enseignement. Paris: Les Éditions de Minuit.

Bourdieu, P. \& Passeron, J-C. (1992). Reproduction in Education, Society and Culture. London: Sage Publications. Engelsk andenudgave publiceret som: Bourdieu, P. \& Passeron, J-C. (1992). Reproduction in Education, Society and Culture. 2nd. edition, London: Sage Publications.

Broady, D. (1991). Sociologi och epistemologi. Om Bourdieus författarskap och den historiska epistemologin. Skeptronserien. Stockholm: HLS Förlag.

Callewaert, S. (1992). Kultur, pædagogik og videnskab. Om Pierre Bourdieus habitusbegreb og praktikteori. København: Akademisk Forlag.

Callewaert, S. (2003). Kulturel kapital og social differentiering. I anledning af en

konference på Socialforskningsinstituttet om levevilkår. I Fra Bourdieus og Foucaults

verden. Pædagogik og sociologi, diskurser og praktikker, efter det moderne. København:

Akademisk Tid \& Tanke, pp. 129-149.

Gesser, B. (1990): Utbildning, Jämlikhet, Arbetsdelning. Lund: Arkiv.

Habermas, J. (1981). Theorie des kommunikativen Handelns. Frankfurt am Main: Suhrkamp.

Habermas, J. (1996). Teorien om den kommunikative handlen. Aalborg Universitetsforlag: Aalborg.

Palme, M. (2008). Det kulturella kapitalet. Studier av symboliska tillgångar i det svenska utbildningssystemet 1988-2008. Acta Universitatis Upsaliensis. Studier i utbildnings- och kultursociologi 1. (http://urn.kb.se/resolve?urn=urn:nbn:se:uu:diva-9411). 